DOI: 10.2478/pof-2018-0016

VOLUME 10, ISSUE 2, 2018

ISSN: 2036-5438

\title{
Beyond Second Chambers: Alternative Representation of Territorial Interests and Their Reasons
}

by

\author{
Francesco Palermo*
}

Perspectives on Federalism, Vol. 10, issue 2, 2018 


\begin{abstract}
The paper contends that bicameral systems, irrespective of their differences in composition and powers, are unfit to represent territorial interests in the national decisionmaking process, except in some residual cases. What subnational entities seek is participation rather than representation. This is why alternative, executive-based institutions in which also the national government is present are mushrooming and second chambers are ineffective as territorial bodies. Furthermore, there is a clear trend to move from bicameralism to bilateralism, meaning that instead of taking advantage of ineffective multilateral institutions, strong subnational units try to channel their claims through bilateral instruments. Overall, the unresolved dilemma of subnational representation has little to do with the architecture of second chambers and rather lays in the tension between individual and collective representation.
\end{abstract}

\title{
Key-words
}

second chambers, inter-governmental relations, representation, participation, federalism, bilateralism 


\section{Introduction}

Second chambers are often considered the litmus test of federal systems. Based on a very partial idea of federalism as aggregative process of previously sovereign entities ${ }^{\mathrm{I}}$, territorial second chambers should represent the institutional compromise according to which subnational units participate in the national decision-making (mostly in legislation, but not only) in exchange of their loss of sovereignty.

Such a view is however very partial and above all it does not reflect comparative constitutional reality. It is partial, since most territorial second chambers ${ }^{\mathrm{II}}$ have not been established according to this logic and are indeed composed in a way that does not fully represent subnational entities in the national level. Even more relevant is the fact that comparative constitutional reality tells a very different story as to the representation of subnational unities at the national level, which is that of unfitness of such bodies, irrespective of their set ups and powers, to serve as the voice of subnational units. This paper will start with some reflection on the widespread misunderstanding as to role and function of territorial second chambers (2.), it then looks at alternatives that have been developed in comparative perspective (3.), it focuses on the bilateral trend that is emerging as a consequence of the ineffective and merely collective representation that second chambers can offer (4.) and it concludes by arguing that territorial participation in decisionmaking at national level is far more relevant than territorial representation (5.). Therefore, to represent regions, a fundamental challenge of bicameralism is necessary.

\section{Romanticizing and misunderstanding second chambers: the Madison's Paradox}

The difficulties and even the impossibility of territorial second chambers in doing what they were supposedly designed for - i.e. represent subnational units and their interests in the national decision-making process - has emerged from the very beginning of this experiment. Based on the experience of the Philadelphia convention and the invention of the US Senate as the prototype of federal second chamber, the unfitness of such chambers 
to effectively represent subnational interests at the national level has been labelled as 'Madison's paradox' (Dehousse 1989).

Although Madison claimed that the Senate 'will derive its powers from the states as political and coequal societies' (Hamilton, Jay and Madison, 1987: 122), it did not evolve as an institution representing states interests (Patterson and Mughan 1999: 11) and was probably never supposed to do so (Doria 2006). The depiction of the Senate in The Federalist as stronghold of states interests and, indeed, as an heir to the Congress during confederation is thwarted by a constitutional design that weakened the link between the states and their supposed representatives. Senators were appointed only until 1913 by the state legislatures and the abolition of instruction and recall shielded them from state influence, making them powerful political representatives whose influence is very little if at all dependent on their electoral constituency.

Furthermore, contrary to what the ex post justification suggested to mute anti-federalist critique, the design of the Senate did not quite result from conceptual considerations as a symbol of the states being still equal. It was rather the result of a pragmatic bargain, the socalled Connecticut Compromise (also known as the Sherman Compromise or Great Compromise), to please the smaller states so that it is rather muddleheaded to romanticize a necessary bargain into a grand principle of democratic politics' (Dahl 1956: 112) ${ }^{\mathrm{III}}$.

Arguably, there was, however, an element of principle insofar, as the Senate was to reflect the theory of mixed government blending aristocratic and democratic elements, as espoused by British Whigs and Montesquieu (Wood 1998). As an 'American House of Lords' (Swift 2002: 9) it had, like many other cornerstones of the new federation, the function of protecting against excesses of democracy ${ }^{\mathrm{IV}}$.

Be it as it may, the Madison's paradox tells that territorial second chambers, aimed at representing territories and more generally factors other than the democratic element, in the end turned out to do precisely what they were supposedly aimed at not doing. They became political-democratic chambers like the lower houses of parliament, even more in the case of the US Senate as it has considerably more powers than the House of Representatives. Such evolution has not been immediately perceivable, but established itself in the course of history when the democratic element eventually prevailed over any other constitutive element of constitutional democracy. The turning point in history for such development was the early $20^{\text {th }}$ century: under the Australian constitution of 1900 , the 
Senate was designed as directly elected by popular vote and the same was introduced in the US by the XVII amendment in 1913. The same happened in the US-modelled federations in Latin America: Mexico, Argentina, Brazil.

The Madison's Paradox is confirmed by its sole (apparent) exception, the German Bundesrat. This is in a way the only second chamber truly representing subnational entities and it does so (at least in principle) because it is not a chamber, as confirmed by the Federal Constitutional Court in $1974^{\mathrm{V}}$. In fact it could not be a chamber due to its structural features: ambassadorial model (members are more similar to ambassadors rather than to members of Parliament - Doria 2006), imperative mandate and compact vote (votes are to be cast together) $^{\mathrm{VI}}$. Not being constitutionally a second chamber, it politically became one such, due to the unstoppable tendency of collective bodies to act according to political rather than territorial logic (Luthardt 1999 and Hennis 1998: 159). Therefore, even functional equivalents to territorial second chambers face the same problem: the dominance of the political over the territorial element, inevitably pushed by the dominance of the democratic over the territorial legitimacy. The dominance of the democratic element is in fact a typical feature of modern and contemporary constitutionalism and parliamentarism. This is why the German model is always admired and looked at (and often overestimated) but never copied ${ }^{\mathrm{VII}}$. In the end, a chamber is simply not the right place to represent territories as it is structurally unfit to perform such function (Ruggiu 2006).

\section{Alternative forms of representation: rather seeking participation?}

If a territorial chamber is structurally ineffective as far as effective representation of territories is concerned, it does not mean that the problem of representing regions does not exist. To the contrary, it becomes all the more acute precisely because of the wrong expectation that this might be done through territorial second chambers. As it normally happens in law, if a problem cannot be solved using the prime instrument designed for that, other mechanisms are developed, first informally and subsequently in a more formalized way. Such instruments typically do not replace the former but coexist with them and simply take over (some of) their functions. 
This is precisely what has happened with the representation of territorial claims and interests in the national decision-making. While in some exceptional cases other forms of representation have been adopted within the parliamentary system, as a rule the deficits of representation are compensated by means of inter-governmental, executive-based bodies.

\subsection{Alternative forms within parliaments}

In some cases the parliamentary way for territorial representation is chosen, although not by means of a dedicated chamber. This is the case of constitutionally granted representation of specific territories within unicameral Parliaments, irrespective of the numerical consistency of the territory's population. Most notable examples are islands autonomies (Ackrén and Olausson 2008 and Hepburn 2012). For instance, in the Parliament of Papua New Guinea four representatives have to come from the autonomous island of Bougainville, in the Danish Parliament two representatives are reserved to Greenland and two to the Fær Øer islands, in the Finnish Parliament one representative is assigned to the Aland islands ${ }^{\mathrm{VIII}}$ and five members of the Parliament of Tanzania are elected by the Zanzibar House of Representatives. Such form of preferential representation takes place in unicameral parliaments ${ }^{\mathrm{IX}}$, which makes it a functional equivalent to territorial bicameralism, just for specific territories only that enjoy a higher degree of autonomy or are the only autonomous territories within a unitary state. A creative variation of parliamentary subnational representation can be found in Italy, where representatives of the regions might integrate the bicameral committee on regional affairs, although this procedure has never been activated ${ }^{\mathrm{X}}$.

These peculiar forms of territorial representation in parliaments are functional equivalents to territorial second chambers, and face precisely the same deficits: the usual dominance of the political over the territorial criterion and unfitness to effectively voice individual interests. Individual interests can sometimes be channeled through territorial second chambers, although only in exceptional and 'existential' cases, i.e. when the survival of the very representation in the second chamber is at stake. Examples can be found in article V US constitution $^{\mathrm{XI}}$ and, in a softer version, in article 35.4 Austrian constitution $^{\mathrm{XII}}$.

Since parliamentary representation inevitably turns out to be political and not territorial in nature, effectiveness can be achieved when the territorial and the political element coincide and overlap. This is the case of strong territorial parties which appoint most or 
even all members of the (first and second) chamber coming from a particular region. This is however a merely political and by no means an institutional solution.

\subsection{Executive-based institutions}

If parliamentary institutions are unfit to represent territories, the logical alternative are institutions representing the executives. Irrespective of the very existence and of the composition and powers of territorial second chambers, nearly everywhere, more or less institutionalized bodies have been established to link subnational entities and the centre at the governmental level.

As part of the wider inter-governmental relations, these institutions present two fundamental elements that differ from territorial second chambers and make them way more effective. First, they are executive, not parliament-based institutions, being composed of representatives of the subnational governments, i.e. of the institutions that really determine subnational policies and are responsible for their implementation (as well as, in many cases, also of considerable parts of national policies). Second, such bodies normally include representatives of the national government as well and are thus institutions that ensure primarily participation and coordination rather than mere representation.

Examples are countless and exist everywhere (Poirier, Saunders and Kincaid 2015), both in traditional (older, coming-together) federal systems and in more recent, devolutionary federal/regional systems. They exist both where traditional federal second chambers are in place, and where second chambers were not born as institutions representing subnational units (such as in devolutionary federal systems but also in Canada), and even in Germany, the only system where an executive-based (functional) second chamber is in place. This means that they are essential irrespective of the existence and of the structure, the powers and the functions of second chambers. Furthermore, such institutions might be self-explaining in cooperative federal systems and more difficult to accept, from a systematic point of view, in dual federations, but they exist even in the latter. While these institutions have somehow always existed since the inception of each federal system, they mushroomed in the past 40 years, when the era of cooperative federalism boomed, although their formalization depends on the evolution and the features of each federal system ${ }^{\mathrm{XIII}}$. There is thus an obvious link between subnational participation and cooperative federalism, which inevitably shifts the balance on the side of the executives. 
Not by chance, the more cooperative the federal system, the more it is defined as 'executive' federalism ${ }^{\mathrm{XIV}}$. Executives have in fact a number of instruments at their disposal that can steer and value subnational participation, both directly and indirectly - examples of the latter are for instance the external activities of subnational units (state treaties with other subnational units in the same country, with national or subnational foreign governments, participation in international bodies, and the whole range of informal activities ensuring participation in an increasingly interconnected world) ${ }^{\mathrm{XV}}$.

Based on these comparative achievements, a few telling examples of such alternative forms will be briefly sketched, both in traditional, coming-together federal systems (with either a 'traditional' senate or with a long history of bypassing second chambers never conceived as proper territorial representation) and in more recent, devolutionary federal or regional systems ${ }^{\mathrm{XVI}}$.

\subsubsection{Traditional federal systems}

'Intergovernmental relations in the United States have always been very fluid and informal. There is nothing in the U.S. system directly comparable to the executive federalism prevalent in some federal systems, such as Canada, nor is there a bevy of joint decision-making bodies common in some federations, such as Germany. Given the dualistic nature of U.S. federalism, in which the U.S. government and the states are cosovereign, state and federal officials have resisted the establishment of formal intergovernmental institutions' (Kincaid 2011: 181). Furthermore, the huge differences in size and claims among the various States and above all the adversarial culture between Republicans and Democrats make it very difficult to set up institutionalized forms of cooperation (O’Toole and Christensen 2013). However, 'intergovernmental relations pervade US politics and policies' (Smith 2015: 432). State and local officials cooperate with each other and place joint pressure on the federal government through their voluntary, nonprofit, national organizations. The oldest (1908) and most significant one is the National Governors' Association which is a sort of political forum of governors of states, territories and commonwealth of the US and is relevant especially for territories such as Puerto Rico, which is otherwise not properly represented in federal bodies ${ }^{\mathrm{XVII}}$. Another relevant institution is the Council of State Governments, a non-partisan regional organization existing since 1933 that provides mostly expertise, coordination, training, but 
little political action. It is worth noting that an Advisory Commission on Intergovernmental Relations existed for a while (1959-1996) and consisted of three members of the President's Cabinet, three U.S. House members, three U.S. senators, four governors, three state legislators, three county commissioners, four mayors, and three private citizens (Kincaid 2011).

Canada has notoriously a very different constitutional history and approach as compared to the US. Also with regard to intergovernmental relations more generally and executive-based institutions representing provincial interests in particular, the situation is different and the practice and tradition of such relations is way more developed, not only due to the Senate's incapacity to represent provincial interests and diversity. From the very beginning of the Canadian federation, provincial prime ministers started to gather together and this became a politically significant forum. Since 1887 the first ministers and the federal prime minister regularly meet a least once a year. Since 1971 this organ is called First Ministers' Conference and despite being politically extremely significant (it is for instance the prime forum to discuss aboriginal issues) it was not mentioned in the Constitution Act 1982. Parallel to the First Ministers' Conference, sectoral conferences called Ministerial Councils exist and regularly meet on specific issues, sometimes supported by permanent secretariats, such as in the case of the Council of Ministers of Education (Adam, Bergeron and Bonnard 2015: 146-153).

Also Australia, like other dual and common-law based federal systems, is generally resisting to the idea of mechanisms bringing together the levels of government, but there also, as in other systems, these have been nevertheless established (Phillimore and Harwood 2015). The most notable body in this respect is the Council of Australian Governments, in place since 1992 (replacing the previous annual Premiers' Conference), comprising the head of governments of all levels (prime minister, premiers and chief ministers) of the Commonwealth, six States and two Territories. Similar institutions exist in other federal systems with mixed or with civil law traditions, such as Argentina (Carnota 2015), Brazil (Arretche 2015), Mexico (Hopkins 1990), India (Singh and Saxena 2015), South Africa (Powell 2015) or Malaysia (Lim 2008).

Moving to Europe, the practice of intergovernmental institutions is even more widespread as the European federal systems are overall marked by greater cooperation among the tiers of government and in most cases are based on the idea of executive 
federalism. In Switzerland there is a deeply rooted tradition of strongly developed horizontal (inter-cantonal) cooperation, although vertical mechanisms and processes involving federal authorities are much less developed (Pfisterer 2015). The constitutional reforms of 2000 and 2008 'enabled the cantons to formally establish joint organizations and institutions, although several already existed previously (Art. 48 federal constitution)' (Pfisterer 2015: 390). The most significant ones are the conferences of the sectoral ministers, that have started to meet informally as early as 1897, and of course the Conference of the Cantonal Governments, founded in 1993 (Hänni, Belser and Waldmann 2013). In recent times, the House of Cantons, established in 2007, increased its importance as a technical secretariat of all intercantonal working groups and governmental committees (Wasserfallen 2015).

In Austria, the Conference of the Land Governors 'works to compensate for the weakness of the Federal Council'. The second chamber of Austria's Parliament is an important institution in federal theory [but] its legal status is comparatively weak' (Bußjäger 2015: 81). The Conference started to meet regularly (at least 2 times a year) as of the 1970s (Rosner and Bußjäger 2011) and was gradually formalized. Now it is mentioned in a few provisions of the federal constitution, such as article $59 \mathrm{~b} \mathrm{~B}-\mathrm{VG}$, which enables it to propose legislation to the Federal Government, and article $36.4 \mathrm{~B}-\mathrm{VG}$, which allows the Land Presidents to participate in the debates of the Bundesrat (Gamper 2017b). Especially the last provision, introduced in 1984, is a prime example of integration of the executivebased cooperative institution with the second chamber. This way, the Land government (in particular its President) serves as a link between a weak second chamber and the subnational units (Schäffer 2007).

The most significant demonstration of the inevitable presence of executive-based participatory institutions comes from the German system, which is the only one where a purely executive (functional) second Chamber exists. Despite the presence and the significant role of the Bundesrat, a wide network of intergovernmental relations exist in Germany, and in particular several bodies where the regional governments, in different compositions, meet among themselves and with the federal government to coordinate policies and actions (Lhotta and von Blumenthal 2015, Benz 2007, Kropp 2010). This goes as far as to include cooperative mechanisms of control, such as the Stability Council to secure the federal and the regional budgets, composed by the federal ministers of finance 
and economy and the regional ministers of finance (article 109a Basic Law) (Lhotta and von Blumenthal 2015: 229).

The reasons for establishing a parallel, highly intertwined system of executive relations are manifold (Scharpf 1976 and Scharpf 2009), including the growing complexity and the related impossibility for one institution, even if intergovernmental in nature like the German Bundesrat, to manage it all. For the purposes of this study, however, one reason seems particularly significant and it is the fact that the Bundesrat does not include representatives of the federal government, while all other intergovernmental institutions do. In other words, the Bundesrat is an institution for representation, while the intergovernmental bodies are institutions of participation. And contemporary federalism is marked by growing interconnection in managing powers, that are ever less exclusive and more and more shared irrespective of the formal distribution laid down in constitutions (Steytler 2017). For these reasons, effective fora for participation on both levels by means of their executives are key in coping with challenges of contemporary governance complexity (Poirier and Saunders, 2015: 491-493).

\subsubsection{Countries with no (or very little) territorial link in second Chambers}

The described trends are even more acute in federal or regional countries whose second chambers never had the ambition to be (fully) territorial. In such systems, subnational participation had to look for alternative channels of participation at the national level from the very beginning, not even trying to use the second chamber for that purpose. These countries are those whose territorial division of power (be it federal or regional in nature $)^{\mathrm{XVIII}}$ originate from progressive devolution of powers from a former unitary state and/or whose second chambers were designed to represent - partly or entirely - different forms of pluralism than the territorial one: political, censual, ethnic, aristocratic. In some case, the territorial element is somehow enshrined in the second chambers, although either only formally (Italy), or ineffectively (Spain) or indirectly (Belgium).

In Spain, the ineffectiveness of the senate despite its constitutional mandate of being a chamber of territorial representation (article 69 const.), led to the establishment of a wide network of ministerial conferences linking the levels of government. The whole system of intergovernmental relations is based on sectoral conferences where ministers or civil servants of the respective ministries of the national and subnational level discuss issues of 
common regional interest and prepare the ground for formal decisions to be taken by the formal (mostly legislative) bodies (García Morales and Arbós Marin 2015). Such conferences have been progressively established from the early 1980s onwards and are now as many as 47 , covering all possible sectors of public administration ${ }^{\mathrm{XIX}}$.

Very similar is the situation in Italy, whose senate is elected on a regional base (article 57 const.) but apart from that it is a purely political chamber. Like in Spain, several attempts to reform the senate by transforming it into a 'proper' regional chamber (better: to enhance the link between the regions and the senate) have failed. Against this background, informal intergovernmental conferences have been set up as of the 1970s, when the ordinary regions have been established. As early as 1983, the permanent conference between the state and the regions (and the two autonomous provinces of Trento and Bolzano/Bozen) was established by a ministerial decree, it was then formally regulated by law in 1988 and enhanced in 1997. The conference is the prime institution for political negotiations between the state and the regions as well as the body in which the regions express their view on national policies (Bifulco 2006). The conference can meet in different compositions based on the matter at stake $\mathrm{xx}^{\mathrm{x}}$.

Unlike in Spain and Italy, in Belgium the constitutional reforms regarding the senate have been frequent, although none has turned it into a territorial chamber. Rather, given the features of Belgian federalism, successive reforms have enhanced the role of the senate as a chamber of the linguistic groups. Furthermore, due to the ethno-linguistic cleavages in the country, formal cooperation between the groups (and the territories) as well as between the levels of government has always been quite limited. This started to gradually change towards the end of the 1980s, in preparation of the big federal reform of 1993 and has continued ever since, as a sort of compensation for further devolution of powers. In the early 1990s a study estimated such intergovernmental mechanisms to be around 100 (Lejeune 1990), most of them however procedural rather than institutional in nature. The chief body for subnational participation and conflict prevention is the Concertation Committee, a multilateral body composed of the federal Prime Minister, five federal ministers and six subnational ministers, equally divided between French and Dutch speakers. There are also interministerial conferences and several other specific cooperative organs (Poirier 2002). 
Examples could be endless. From a comparative perspective, however, the trend is absolutely clear: fully irrespective of the nature of second chambers, their powers and effectiveness, alternative, executive bodies based on cooperation are established and are blooming everywhere. These, and not the second chambers (even less if not territorial, of course) are the fora for participation of subnational units in decision-making. And participation, not representation, is what subnational units need and look for at national level. These participatory bodies do exactly what second chambers do not do, i.e. negotiate issues of subnational interest with the national interlocutor, at the level where political power is allocated: the executive.

\section{From bicameralism to bilateralism}

Next to the growth of executive-based institutions for subnational participation at national level, an additional trend is to be noted as far as the relations between the levels of government in federal and regional systems are concerned. Whenever cooperative forms are not (perceived as) sufficient, or when certain territories present a strong (minority) identity or other factors that make them different from the rest of the country, multilateral fora are normally unfit to fulfil their claims for differential treatment. This is because such fora - second chambers or executive-based participatory institutions - work according to the majority principle, and while they often over-represent smaller units, none of them provides individual subnational units with veto rights. This means that multilateral fora cannot ensure that one subnational unit's position is upheld and an alliance among all other entities overrules any individual position.

This is why more and more frequently strong subnational units pursue bilateral instruments for negotiation and cooperation with the national level and very often such fora are legally established since the national level acknowledges that they are necessary. However, the less effective the multilateral instruments or the more adversarial the political relations between individual subnational units and the center, the more bilateral channels are pursued and the multilateral ones ignored or bypassed.

While the political and scholarly discourse too often looks at how second chambers could be made more effective in representing subnational interests, it forgets that the issue is participation, that participation takes place outside of second chambers and that in a 
growing number of cases the main problem is to determine the right balance between individual and collective bargaining between the levels of government. In other words, the fundamental question for subnational representation, participation and cooperation does not concern bicameralism, but increasingly bilateralism. How much bilateralism is necessary and how much is tolerable within a constitutional framework is a matter of complex institutional engineering that depends on many variables in each constitutional system.

In general terms, the growing appeal of bilateralism is due to three main reasons: first, the ineffectiveness of multilateral fora; second, the degree of asymmetry among territories; third the adversarial rather than cooperative political culture. Of course, these factors can also be simultaneously present. By way of example, three European cases could be briefly mentioned to illustrate these underlying reasons and the very different impact of bilateralism in different constitutional and political environments.

The first and older one are the bilateral committees that exist for each of the five Italian special regions for the implementation of the respective autonomy statute ${ }^{\mathrm{XX}}$. Since the special autonomy statutes for Sicily, Sardinia, Friuli Venezia Giulia, Trentino-South Tyrol and Aosta Valley are adopted in form of national constitutional laws (unlike the statutes of the other, 'ordinary' regions that have their own constitutional autonomy but of course are subject to the prevalence of national law), their implementation also has to be carried out in a bilateral negotiation procedure. To this end, for each region a bilateral committee is set up, composed of equal number of representatives of the respective region and of the national government, tasked with the elaboration of norms implementing the statutes. Such norms are then adopted in form of governmental decrees (i.e. they bypass the national as well as the regional parliament) and cannot be amended by laws of parliament ${ }^{\mathrm{XXII}}$. There is however a deep difference among the concerned regions as far as the use of such implementing norms is concerned, both in terms of quantity and of quality. Implementing decrees to the autonomy statute of Trentino-South Tyrol have reached so far the impressive number of 190, which is twice as much as Aosta, three times more than Friuli Venezia Giulia and more than four times the total amount of norms adopted for Sicily and Sardinia respectively. As to quality, such norms have been extensively used in TrentinoSouth Tyrol also in order to regulate key fields and to acquire additional competences, such as, inter alia, the production of energy, the roads and other infrastructure, national parks, 
trade, teachers and personnel of justice administration (Cosulich 2017: 111). In sum, the extent to which these powerful bilateral instruments have been used very much varies among the regions due to political and other factors.

A second example of bilateralization, mostly grounded in the lack of trust between the levels of government, is the trajectory of the second autonomy statute of Catalonia as far as the relations with the Spanish state are concerned. In order to avoid, to the extent possible, judicial struggles over the delimitation of powers (that were mostly adjudicated in favour of the state and not of the Catalan government), the drafters of the revised autonomy statute adopted in 2006 decided to establish ironclad safeguards (so called 'armor plate') for the competences of the autonomous community against state intervention by regulating in great detail the scope of the autonomous powers (Albertí Rovira 2005 and Cruz Villalón 2006). Furthermore, to the same end of limiting the state influence on Catalan selfgovernment, an extremely detailed regulation of 'institutional relations of the Generalitat' was introduced in the statute, consisting of 26 articles (174-200). In particular, article 183 established a 'Generalitat - State Bilateral Commission' as the 'general and permanent framework for relations between the Government of the Generalitat and the Government of the State'. The commission should have become the chief institution for negotiations between the Catalan and the Spanish government, which would have become entirely and exclusively bilateral. For this reason, the famous and contested ruling of the Spanish constitutional court on the constitutionality of the Catalan statute of $2010^{\text {XXIII }}$ interpreted this provision in a constitutionally conform way by fundamentally limiting the scope of the commission and of the general principle of bilateral relations established in article 3.1 of the statute of autonomy ${ }^{\mathrm{xxI}}$. The resulting frustration of the claim for bilateralism has been one of the reasons causing the spillover that took place in Catalonia after the ruling (Castellà Andreu 2016).

Another case worth mentioning is that of the bilateral relations between the autonomous territorial unit (ATU) of Gagauzia and the state of Moldova, to which it belongs. This peculiar case supports the achievements of this study with regard to the uselessness of parliamentary bodies to serve as fora for negotiations of subnational interests. In the Moldovan case, the parliamentary way has been pursued not by establishing a territorial second chamber, but by parliamentarising bilateral relations with the subnational autonomous entity of Gagauzia. The autonomy of the ATU of Gagauzia 
was established in 1994 after some violent incidents that affected that region in the aftermath of the civil war in Transdnistria that led to the de facto split of that region from Moldova in 1992. To settle down the conflict, a far-reaching territorial and cultural autonomy was granted in 1994 by means of a special law on autonomy, which however remained largely unimplemented (Protsyk 2010). To set the process in motion, a dialogue process has been started, which included the establishment of a parliamentary working group between the Moldovan Parliament and the People's Assembly of Gagauzia that has begun to work on specific legislative proposals to improve incorporation of the existing autonomous powers within the Moldovan legal and administrative system. The working group has been working for some years but has not produced tangible results so far, also due to the fact that is members changed after every national and subnational election and that the process was highly politicized.

\section{Conclusions. Real vs apparent challenges}

Subnational representation and participation at national level is a key issue when looking at the functioning of federal and regional systems. The comparative analysis of the instruments to (try to) achieve that aim shows interesting and challenging trends. However, they go often unnoticed in literature and in political discourse.

There is, in general, a widespread trust in second chambers that does not match reality. This is not to say that (territorial) second chambers are not useful for several purposes, but simply that they are structurally unable to become effective fora for subnational participation in the national decision-making process. They are suited, in the best case, to represent subnational entities according to a very formalistic approach to representation, but due to the prevalence of the political-parliamentary logic over the territorial one they are in practice unable to be the place where the levels of government meet and negotiate issues of subnational (and of general) interest. Very often the reform of the second chamber is presented as a solution to the problems of the federal structure in several countries, but after all no reform has succeeded to turn second chambers into something they are not designed to be $\mathrm{xxv}^{\mathrm{x}}$.

For this reason, alternative institutions made up of representatives of the subnational and national executives are mushrooming, bypassing ${ }^{\mathrm{xx}}$ second chambers as multilateral 
fora for participation in decision-making. The key for success of such institutions lays precisely in these two elements: as executive-based bodies, they can politically commit their respective level, whereas a parliamentary body cannot but be based on free mandate; furthermore, and even more importantly, they do not simply represent subnational units, but bring together both levels of government, thus enabling for negotiation. In fact, in today's complex multi-level scenery, participation is way more important to subnational units than mere representation.

Participatory, multilateral bodies are effective as platforms for negotiating issues of general interest for the subnational level, much less when it comes to specific requirements of individual subnational units. Such bodies only work where subnational units have strong common interests and are ready to cooperate among themselves, i.e. in symmetric systems with a strong cooperative culture and rather homogenous territorial claims. When such conditions are not met, the need arises to establish institutions where individual subnational interests can be voiced bilaterally, since majority decisions can suppress individual claims. Rather than looking at impossible ways to make second chambers the central bodies for representing territorial interests, the really pressing issue is to find the right balance between individual and collective subnational interests. Too much of the former produces separation and alienation, too much of the latter suppresses the need for different treatment in different cases.

A wrong diagnosis produces a wrong therapy. Therefore, reflection is needed on the relations between levels of government by asking the right questions. Otherwise, law abdicates to its prime function of solving problems.

\footnotetext{
* Francesco Palermo is Professor for Comparative Constitutional Law, University of Verona and Director, Institute for Comparative Federalism, Eurac Research, Bolzano/Bozen, Italy. Full CV at www.eurac.edu/fpalermo.

I For theoretical and historical considerations and further literature Palermo and Kössler 2017:24-80.

II For classification of second chambers see the paper by P. Passaglia in this issue. See also Luther, Passaglia and Tarchi 2006, Schmidt 2016 and Palermo and Nicolini 2013.

III The Federalists even conceded this bargain nature: 'But it is superfluous to try, by the standard of theory, a part of the Constitution which is allowed on all hands to be the result, not of theory, but 'of a spirit of amity, and that mutual deference and concession which the peculiarity of our political situation rendered indispensable.... A government more consonant to the wishes of the larger States is not likely to be obtained from the smaller States', Federalist No. 62.

IV This is best illustrated by an anecdote of George Washington explaining to Thomas Jefferson, who had been absent from the Constitutional Convention, the function of the Senate: 'Washington asked, 'Why do you pour your coffee into your saucer?' Jefferson replied, 'To cool it.' 'Even so,' Washington responded, 'we pour legislation into the senatorial saucer to cool it'. Patterson and Mughan, 1999: 15.

v BVerfGE 37, 363.
} 
VI In fact, especially when the political majority in the Bundesrat is different from the one that supports the federal government in the Bundestag, the Federal Council can become an instrument of political opposition. An interesting case when for political reasons even the principle of compact vote was challenged took place in 2002, when the highly contested reform of immigration law was put to a vote in the Bundesrat (dominated by a conservative majority) after having been passed in the Parliament (then controlled by a social-democratic and green majority). The Land Brandenburg, than ruled by a coalition between christian-democrats (opposition to the federal government) and social-democrats (supporting the federal government) could not agree on a common position and instead of abstaining from voting in the Bundesrat as it happens in such cases, decided to go ahead by splitting the four votes of the Land in the Council, which was subsequently considered unlawful by the Federal Constitutional Court (BVerfGE 106, 310).

VII Some features of the German (ambassadorial) model can be found in the South African National Council of Provinces, although the composition is very different and the compact vote can be cast only in exceptional cases. More similarities can be found with the Council of the European Union.

VIII Interestingly, since 1948 the Åland parties form a coalition for the Finnish elections and in Helsinki they normally join the parliamentary group of the Swedish people's party, thus maximizing their presence by means of political coalition with other ethnic kins in the host country, which is an option the other island autonomies do not have.

Ix An exception is the smallest Italian region (Aosta Valley), which by virtue of the constitution has one guaranteed senator (art. 57.3 Italian constitution).

$\mathrm{x}$ Art. 11 const. Law no. 3/2001. Even if activated, however, the regional representation would remain entirely political.

XI 'No state, without its consent, shall be deprived of its equal suffrage in the Senate'.

XII Here the veto is not individual but by a qualified minority of Länder (four out of nine) and the votes are not cast en bloc. See Gamper 2017a.

XIII For example, one would never expect to see them constitutionalized in countries such as the US, while it was quite natural that a partial constitutionalization took place in Austria a Switzerland. Poirier and Saunders, 2015: 488-489 mention six main reasons for the different degree of institutionalization of intergovernmental relations: 1) modernity (the older the federations, the less room for formalized intergovernmental relations); 2) the degree of trust between orders of government (the lower the trust, the more likely is formalization), the strength or fragility of subnational units (the more fragile, the more formalized such bodies tend to be); 4) identification of subnational units with minority groups (if so, normally more formalization is demanded); 5) legal culture (stronger formalization is to be noted in civil law countries); 6) democratic accountability (greater institutionalization may be a response to a lack of it).

XIV See Watts 1989.

xV See recently Medeiros (ed) 2018.

XVI In all mentioned cases, also some (normally low formalized) institutions bringing together the subnational assemblies are in place. While forming part of the wider intergovernmental relations, they won't be mentioned here as they do not perform the same function of representation of subnational interests as executive-based ones.

XVII More precisely, Puerto Rico has no voting representative in the US Congress but has a Resident Commissioner who has voice in congress but no vote.

XVIII As mentioned, no substantial constitutional difference can be identified between the two categories, although such difference might exist in the perception of the federal ideal as well as in the historical evolution of the territorial relations. See Gamper 2005.

XIX See full list at http://www.seat.mpr.gob.es/dam/es/portal/areas/politica autonomica/coop autonomica/Conf Sectoriale s/Documentacion/Conf Sect exist/parrafo/0/CONFERENCIASSECTORIALES REGIMEN JURIDICO ACTUALIZADO0.pdf.

$\mathrm{xx}$ For issues affecting also the local government, the conference meets in joint composition with the homologous conference between state and municipalities. In such case it is called 'unified conference'.

XXI See recently Cosulich 2017. In English and with regard to the most significant experience, that of the autonomous provinces of Trento and Bolzano, see Palermo 2008.

XXII As repeatedly confirmed by the constitutional court - see inter alia rulings no. 20/1956, 22/1961, 151/1972, 180/1980, 237/1983, 212/1984 e 160/1985, 213/1998.

XXIII STC 31/2010. Among the countless comments to this ruling see the special issue of the Revista Catalana 
de Dret Públic, Especial Sentència 31/2010 del Tribunal Constitucional, sobre l'Estatut d'autonomia de Catalunya de 2006, available online at http://revistes.eapc.gencat.cat/index.php/rcdp/issue/view/23.

xxIV STC 31/2010, para 115.

xxv Examples are countless. In Spain, since the adoption of the 1978 constitution, the reform of the senate is considered the way for a functioning territorial setting (Aja and Albertí Rovira 2005) and very recently a group of distinguished Spanish constitutional lawyers have proposed a reform to the constitution to solve the Catalan (and more generally the territorial) crisis in which the reform of the senate according to the German (or, alternatively, to the Austrian) Bundesrat would be the key for the change (http://idpbarcelona.net/docs/actual/ideas reforma constitucion.pdf). Interestingly, in Germany the Bundesrat has been long considered a stumbling block for an effective, accountable and speedy decisionmaking (Fischer, Hirscher, Margedant, Schick and Werner 2004; Sturm 2003; Lhotta 2003; Bauer 2002; Wassermann 2003), and while structural changes have turned out to be politically and constitutionally not feasible, fine-tuning on the division of powers thus reducing the number of the laws requiring Bundesrat's approval was the main goal of the 'Federalism reform I' adopted in 2006. In Italy the constitutional reform adopted by the Parliament in 2016 but rejected by popular referendum that same year was focused on the reform of the senate and on its supposed regionalization. In Canada the possible reform of the senate has equally been on the political agenda at regular intervals (Docherty 2002) and has recently been revived by a proposal of the government elected in 2015. In Belgium, successive federal reforms have affected the senate, most significantly the most recent one in 2012-2014 (Dandoy, Dodeigne, Reuchamps and Vandeleene 2015), but still did the Senate not become the forum for subnational participation.

xxvI Occasionally also to support, as seen for the Austrian case.

\section{References}

- Ackrén Maria, Olausson Pär M., 2008, 'Condition(s) for Island Autonomy', International Journal on Minority and Group Rights, XV(2): 227-258.

- Adam Marc-Antoine, Bergeron Josée and Bonnard Marianne, 2015, 'Intergovernmental Relations in Canada: Competing Visions and Diverse Dynamics', in Poirier Johanne, Saunders Cheryl and Kincaid John (eds), Intergovernmental Relations in Federal Systems, Oxford Univ. Press, 135-163.

- Aja Eliseo and Albertí Rovira Enoch (eds), 2005, La reforma constitucional del Senado, Centro de estudios constitucionales, Madrid.

- $\quad$ Albertí Rovira Enoch, 2005, 'El blindatge de les competències i la reforma estatutària', Revista Catalana de Dret Public, no. 31: 109-136.

- Arretche Marta, 2015, 'Intergovernmental Relations in Brazil: An Unequal Federation with Symmetrical Arrangements', in Poirier Johanne, Saunders Cheryl and Kincaid John (eds), Intergovernmental Relations in Federal Systems, Oxford Univ. Press, 108-134.

- Bauer Hartmut, 2002, 'Entwicklungstendenzen und Perspektiven des Föderalismus in der Bundesrepublik Deutschland‘, Die öffentliche Verwaltung, 837-845.

- Benz Arthur, 2007, 'Inter-regional competition in co-operative federalism: New modes of multi-level governance in Germany', Regional \& Federal Studies, XVII(4): 421-436.

- Bifulco Raffaele, 2006, 'Il modello italiano delle conferenze Stato-autonomie territoriali (anche) alla luce delle esperienze federali', Le Regioni, XXXIV(2-3): 233-268.

- Bußjäger Peter, 2015, 'Intergovernmental Relations in Austria: Co-operative Federalism as Counterweight to Centralized Federalism', in Poirier Johanne, Saunders Cheryl and Kincaid John (eds), Intergovernmental Relations in Federal Systems, Oxford Univ. Press, 81-107.

- Carnota Walter F., 2015, 'Intergovernmental relations in Argentina: Systematic Confusion and Predominance of the Centre', in Poirier Johanne, Saunders Cheryl and Kincaid John (eds), Intergovernmental Relations in Federal Systems, Oxford Univ. Press, 14-41.

- Castellà Andreu Josep Maria, 2016, 'Tribunal constitucional y proceso secesionista catalán: respuestas jurídico-constitucionales a un conflicto político-constitucional', Teoría y Realidad Constitucional, no. 37: 561-592.

- Cosulich Matteo, 2017, Il decreto attuativo di attuazione statutaria nelle regioni ad autonomia speciale, ESI, Napoli. 
- Cruz Villalón Pedro, 2006, 'La reforma del Estado de las autonomías', Revista d'Estudis Autonòmics $i$ Federals, no. 2: 77-99.

- $\quad$ Dahl Robert A., 1956, A Preface to Democratic Theory, University of Chicago Press.

- Dandoy Régis, Dodeigne Jérémy, Reuchamps Min and Vandeleene Audrey, 2015, 'The New Belgian Senate. A (Dis)Continued Evolution of Federalism in Belgium?', Representation - Journal of Representative Democracy, LI(3): 327-339.

- Dehousse Renaud, 1989, 'Il paradosso di Madison: riflessioni sul ruolo delle camere alte nei sistemi federali', Le Regioni, XVII(6) 1365-1400.

- Docherty David, 2002, 'The Canadian Senate: Chamber of Sober Reflection or Loony Cousin Best Not Talked About', Journal of Legislative Studies, VIII(3): 27-48.

- Doria Giancarlo, 2006, 'The Paradox of Federal Bicameralism', 5 European Diversity and Autonomy Papers 1, 19-26.

- Fischer Thomas, Hirscher Gerhard, Margedant Udo, Schick Gerhard and Werner Horst, 2004, Föderalismusreform in Deutschland. Ein Leiffaden zur aktuellen Diskussion und zur Arbeit der Bundesstaatskommission, Bertelsmann Stiftung, Gütersloh.

- Gamper Anna, 2005, 'A “Global Theory of Federalism”: The Nature and Challenges of a Federal State', German Law Journal, VI(10): 1297- 1318.

- Gamper Anna, 2017a, 'Artikel 35 B-VG', in Korinek Kark, Holoubek Michael et al (eds), Österreichisches Bundesverfassungsrecht, Verlag Österreich/C.F. Müller, Wien.

- Gamper Anna, 2017b, 'Artikel 36 B-VG', in Korinek Karl, Holoubek Michael et al (eds), Österreichisches Bundesverfassungsrecht, Verlag Österreich/C.F. Müller, Wien.

- García Morales Maria Jesús and Arbós Marin Xavier, 2015, 'Intergovernmental Relations in Spain: An Essential but Underestimated Element of the State of Autonomies', in Poirier Johanne, Saunders Cheryl and Kincaid John (eds), Intergovernmental Relations in Federal Systems, Oxford Univ. Press, 350-378.

- Hamilton Alexander, Jay John and Madison James, 1987, Federalist Papers, Penguin Books, London.

- Hänni Peter, Belser Eva Maria and Waldmann Bernhard (eds), 2013, 20 Jahre KdK, Publikationen des Instituts für Föderalismus, vol. 4, Stämpfli, Bern.

- Hepburn Eve, 2012, 'Recrafting Sovereignty: Lessons from Small Island Autonomies?', in Gagnon Alain and Keating Michael (eds) Political Autonomy and Divided Societies. Comparative Territorial Politics, Palgrave Macmillan, London, 118-133.

- Hopkins Jack W., 1990, 'Intergovernmental Relations in Mexico and the United States: A Comparative Perspective', International Review of Administrative Sciences, LVI(3): 403-420.

- $\quad$ Kincaid John, 2002, 'Intergovernmental relations in the United States of America', in Poirier Johanne and Saunders Cheryl (eds), Intergovernmental Relations in Federal Systems, McGill-Queen's University Press, Montreal-Kingston, 33-44.

- $\quad$ Kincaid John, 2011, 'The U.S. Advisory Commission on Intergovernmental Relations: Unique Artifact of a Bygone Era', Public Administration Review, LXXI(2): 181-189.

- Kropp Sabine, 2010, Kooperativer Föderalismus und Politikverflechtung, Verlag für Sozialwissenschaften, Wiesbaden.

- Lejeune Marc, 1990, 'Les mecanismes de prevention des conflits d'intérêts', in Alen André (ed), Les conflits d'intérêts. Quelle solution pour la Belgique de domain?, La Charte, Namur, 40-89.

- Lhotta Roland, 2003, 'Zwischen Kontrolle und Mitregierung. Der Bundesrat als Oppositionskammer?', Aus Politik und Zeitgeschichte, B 43: 16-22.

- Lhotta Roland and von Blumenthal Julia, 2015, 'Intergovernmental Relations in the Federal Republic of Germany', in Poirier Johanne, Saunders Cheryl and Kincaid John (eds), Intergovernmental Relations in Federal Systems, Oxford Univ. Press, 206-238.

- $\quad$ Lim Regina, 2008, Federalism-State Relations in Sabah, Malaysia, ISEAS, Singapore.

- $\quad$ Luthardt Wolfgang, 1999, 'Abschied vom deutschen Konsensmodell? Zur Reform des Föderalismus', Aus Politik und Zeitgeschichte, B 13: 12-23.

- $\quad$ Luther Jörg, Passaglia Paolo and Tarchi Rolando (eds), 2006, A World of Second chambers. Handbook for Constitutional Studies on Bicameralism, Giuffrè, Milan.

- $\quad$ Medeiros Eduardo (ed), 2018, European Territorial Cooperation, Springer, New York. 
- O’Toole Laurence and Christensen Robert, 2013, American Intergovernmental Relations, 5 ${ }^{\text {th }}$ ed., Sage, London.

- Palermo Francesco, 2008, 'Implementation and Amendment of the Autonomy Statute', in Woelk Jens, Palermo Francesco and Marko Joseph (eds), Tolerance through Law, Martinus Nijhoff, Leiden-Boston, 143-159.

- Palermo Francesco and Kössler Karl, 2017, Comparative Federalism. Constitutional Arrangements and Case Law, Hart, Oxford.

- Palermo Francesco and Nicolini Matteo, 2013, Il bicameralismo. Pluralismo e limiti della rappresentanza in prospettiva comparata, ESI, Napoli.

- Patterson Samuel and Mughan Anthony, 1999, 'Senates and the Theory of Bicameralism' in Patterson Samuel, Mughan Anthony (eds), Senates: Bicameralism in the Contemporary World, Ohio State University Press, Cleveland.

- Pfisterer Thomas, 2015, 'Intergovernmental Relations in Switzerland: An Unfamiliar Term for a Necessary Concept', in Poirier Johanne, Saunders Cheryl and Kincaid John (eds), Intergovernmental Relations in Federal Systems, Oxford Univ. Press, 379-410.

- Phillimore John and Harwood Jeffrey, 2015, 'Intergovernmental Relations in Australia: Increasing Engagement within a Centralizing Dynamic', in Poirier Johanne, Saunders Cheryl and Kincaid John (eds), Intergovernmental Relations in Federal Systems, Oxford Univ. Press, 42-80.

- Poirier Johanne, 2002, 'Formal Mechanisms of Intergovernmental Relations in Belgium', Regional and Federal Studies, XII(3): 24-54.

- Poirier Johanne and Saunders Cheryl, 2015, 'Conclusion', in Poirier Johanne, Saunders Cheryl and Kincaid John (eds), Intergovernmental Relations in Federal Systems, Oxford Univ. Press, 440-498.

- $\quad$ Poirier Johanne, Saunders Cheryl, Kincaid John (eds) 2015, Intergovernmental Relations in Federal Systems. Comparative Structures and Dynamics, Forum of Federations and IACFS, Oxford Univ. Press.

- Powell Derek, 2015, 'Constructing Developmental State in South Africa: The Corporatization of Intergovernmental Relations', in Poirier Johanne, Saunders Cheryl and Kincaid John (eds), Intergovernmental Relations in Federal Systems, Oxford Univ. Press, 305-349.

- $\quad$ Protsyk Oleh, 2010, 'Gagauz autonomy in Moldova: the real and the virtual in post-Soviet state design', in Weller Marc and Nobbs Katherine (eds), Asymmetric Autonomy and the Settlement of Ethnic Conflicts, University of Pennsylvania Press, Philadelphia, 231-251.

- Rosner Andreas and Bußjäger Peter (eds) 2011, Im Dienste der Länder - im Interesse des Gesamtstaates, Braumüller, Wien.

- Ruggiu Ilenia, 2006, Contro la Camera delle regioni: istituzioni e prassi della rappresentanza territoriale, Jovene, Napoli.

- $\quad$ Schäffer Heinz, 2011, 'Reformperspektiven für den Bundesrat', Journal für Rechtspolitik, XV(1): 11-22

- $\quad$ Scharpf Fritz W., 1976, Politikverflechtung, Vol. 1, Theorie und Empirie des kooperativen Föderalismus in der Bundesrepublik, Scriptor, Kronberg.

- $\quad$ Scharpf Fritz W., 2009, Föderalismusreform: kein Ausweg aus der Politikverflechtungsfalle?, Campus-Verlag, Frankfurt-New York.

- $\quad$ Schmidt Jan Amilcar, 2016, 'Representation of Component Federal Units in Federal Systems', Max Planck Encyclopedia of Comparative Constitutional Law, Oxford University Press.

- Singh Mahendra Prasad and Saxena Rekha, 2015, 'Intergovernmental Relations in India: From Centralization to Decentralization', in Poirier Johanne, Saunders Cheryl and Kincaid John (eds), Intergovernmental Relations in Federal Systems: Comparative Structures and Dynamics, Oxford Univ. Press, 239-271.

- $\quad$ Smith David E., 2003, The Canadian Senate in Bicameral Perspective, University of Toronto Press.

- Smith Troy E., 2015, 'Intergovernmental relations in the United States of America', in Poirier Johanne, Saunders Cheryl and Kincaid John (eds), Intergovernmental Relations in Federal Systems, Oxford Univ. Press, 411-439.

- Steytler Nico (ed), 2017, Concurrent Powers in Federal Systems: Meaning, Making, Managing, Brill, Leiden/Boston.

- $\quad$ Sturm Roland, 2003, 'Zur Reform des Bundesrates. Lehren eines internationalen Vergleiches der Zweiten Kammern', Aus Politik und Zeitgeschichte, B 29-30: 24-31. 
- Swift Elain, 2002, The Making of an American Senate: Reconstitutive Change in Congress, 1787-1841, University of Michigan Press, Chicago.

- Wasserfallen Fabio, 2015, 'The Cooperative Capacity of Swiss Federalism', Swiss Political Science Review, XXI(4): 538-555.

- Wassermann Rudolf, 2003, 'Droht Gesetzgebungsstillstand? - Zur Vetomacht des Bundesrates', Neue Juristische Wochenschrift: 331-332.

- Watts Ronald L., 1989, Executive Federalism: A Comparative Analysis, Queen's University, Kingston.

- Wilhelm Hennis, 1998, Auf dem Weg in den Parteienstaat, Reclam, Stuttgart.

- Wood Gordon, 1998, The Creation of the American Republic: 1776-1787, University of North Carolina Press, Charlotte. 